\title{
Pengaruh Pelatihan Manajemen Stres terhadap Kebahagiaan Santri di Pesantren
}

\section{The Effects of Stress Management Training on Students Happiness in the Pesantren}

\author{
Nefi Darmayanti ${ }^{1}$, Nurussakinah Daulay ${ }^{2}$ \\ ${ }^{1}$ Fakultas Kesehatan Masyarakat, Universitas Islam Negeri Sumatera Utara \\ ${ }^{2}$ Fakultas Tarbiyah dan Ilmu Keguruan, Universitas Islam Negeri Sumatera Utara
}

Submitted 27 April $2020 \quad$ Accepted 12 Mei $2020 \quad$ Published 28 Oktober 2020

\begin{abstract}
This study aimed to determine the effect of stress management training on the happiness of santri at the Uswatun Hasanah Islamic boarding school in Labuhan Batu Selatan district. Experimental pre-post tests with control group design were applied in this study. We obtained the data with a scale of happiness that express the level of satisfaction of the students' life, and positive and negative affects. Subjects in this study were santri aged 14-18 years and had low (14 santri) and medium (36 santri) happiness categorization scores with a moving score range from 106 to 119 . Data were analyzed using a paired sample t-test. The results showed that the experimental group had higher level of happiness $(n=25, M=$ $110.16, S D=9.86)$ than the control group $(n=25, M=101, S D=11.29)$. This difference proved to be significant $(F(1.48)=9.331, p<0.01)$. The effect of stress management training on the happiness of the students was 0.163 or $16.3 \%$.
\end{abstract}

Keywords: happiness; santri; stress management

Abstrak. Penelitian ini bertujuan untuk mengetahui pengaruh pelatihan manajemen stres terhadap kebahagiaan santri di Pondok Pesantren Uswatun Hasanah Kabupaten Labuhan Batu Selatan. Tes eksperimental pre-post dengan desain kelompok kontrol diterapkan dalam penelitian ini. Kami memperoleh data dengan skala kebahagiaan yang mengungkapkan tingkat kepuasan hidup siswa, dan pengaruh positif dan negatif. Subjek dalam penelitian ini adalah santri berusia 14-18 tahun dan memiliki skor kategorisasi kebahagiaan rendah (14 santri) dan sedang (36 santri) dengan rentang skor bergerak 106 hingga 119. Analisis data menggunakan uji paired sample t-test. Hasil penelitian menunjukkan bahwa kelompok eksperimen memiliki kebahagiaan yang lebih tinggi $(n=25 ; M=110,16 ; S D=9,86)$ dibandingkan kelompok kontrol $(n=25 ; M=101 ; S D=11,29)$. Perbedaan ini terbukti signifikan $(F(1,48)=9,331 ; p<0,01)$. Pengaruh pelatihan manajemen stres terhadap kebahagiaan siswa adalah 0,163 atau $16,3 \%$.

Kata kunci: kebahagiaan; manajemen stres; santri

Kebahagiaan bersifat universal, artinya seti-

Korespondensi mengenai artikel ini dapat dilakukan melalui inadaulay82@gmail.com ap manusia mulai dari bayi hingga usia lanjut berhak untuk mendapatkan dan merasakan kebahagiaan dalam hidupnya, baik itu laki-laki maupun perempuan. 
Individu yang bahagia akan mengembangkan kondisi psikologi yang positif, sehingga mudah menjalin relasi sosial dengan orang lain. Senantiasa optimis karena dipenuhi oleh emosi yang positif dan lebih fleksibel dalam menghadapi berbagai tekanan dalam hidup. Sebaliknya, individu yang kurang bahagia akan lebih banyak dikuasai oleh emosi negatif sehingga menjadikannya banyak mengalami hambatan dalam menjalin relasi sosial. Hal ini dipertegas oleh Argyle (2001) menyatakan bahwa dalam konteks kebahagiaan yang dirasakan seseorang menunjukkan adanya emosi positif, kepuasan hidup dan berkurangnya emosi negatif. Selanjutnya Carr (2011) juga berpendapat bahwa kebahagiaan merupakan kondisi psikologi yang positif, yang ditandai dengan kepuasan, meningkatnya emosi positif dan rendahnya emosi negatif.

Demikian sebaliknya, ketidakbahagiaan muncul ketika banyaknya sumber stres yang hadir dalam kehidupannya dan dibarengi dengan ketidakmampuannya dalam mengatasi sumber stres tersebut, hal ini juga tidak luput dari pengalaman santri di pondok pesantren. Ketidakbahagiaan yang dirasakan santri dapat juga bersumber pada kehidupan di pesantren yang padat dengan tugas hafalan surat dan kitab yang harus dipelajari, jadwal belajar yang ketat, serta keterbatasan fasilitas yang ada. Senada dengan hasil penelitian yang dilakukan oleh Aminullah (2013) membuktikan kendala yang dirasakan santri yakni selain merasa kurang bahagia juga mengalami kecemasan, umumnya ketika pada saat akan ujian hafalan dan kegiatan pidato di depan kelas.

Di sisi lain, rasa rindu pada situasi rumah, orang tua dan saudara-saudara seperti kakak atau adik, dapat menambah munculnya perasaan kurang bahagia saat berada di pondok pesantren. Hal ini ditandai oleh kerinduan yang sangat mendalam terhadap situasi di rumah dan hubungan emosional dengan orang-orang yang berarti dalam kehidupannya. Adanya aturan yang ketat dari pihak pesantren yang hanya mengizinkan santri dijenguk seminggu sekali dapat semakin memperparah kondisi homesickness yang mereka alami. Penelitian yang dilakukan oleh Yasmin, Zulkarnain dan Daulay (2017) menemukan bahwa sebanyak 80,41\% (sekitar 182 orang) dari 226 santri yang tinggal di pondok pesantren mengalami homesickness, bahkan sebanyak 4,87\% (sekitar 11 orang) mengalami homesickness yang parah.

Sebelumnya peneliti telah melakukan studi pendahuluan dengan cara focus group discussion terhadap lima belas orang santri dan melakukan wawancara mendalam kepada empat orang santri. Studi pendahuluan dilakukan untuk mengetahui pengalaman santri dan kondisi psikologis yang dirasakan selama berada di pesantren. Tema-tema yang ditemukan berupa: santri merasa tertekan dengan jadwal belajar yang ketat, teman yang kurang mendukung, keterbatasan fasilitas, serta rasa rindu yang dalam terhadap orang tua hingga membuat mereka merasa kurang bahagia. Terkadang juga ada keinginan di antara mereka untuk melarikan diri dari pondok pesantren (Rabu 28 Agustus 2019/ pukul 11.30 WIB). 
Kondisi santri yang tidak bahagia ini membutuhkan penanganan serius, karena jika dibiarkan dapat berakibat pada kondisi yang kurang baik terhadap perkembangan psikologisnya, seperti kurang konsentrasi dalam belajar, kesulitan dalam berinteraksi sosial, kurang mandiri, hingga berujung pada stres. Stres merupakan pengalaman emosi negatif yang diikuti dengan perubahan biokimia, fisiologis, kognitif, dan perilaku dalam rangka mengubah atau menyesuaikan diri dengan pengaruh yang ditimbulkannya (Taylor, 1995), dampak stres berisiko terhadap penurunan kesehatan baik fisik dan mental, serta rendahnya kebahagiaan (Fields \& Prinz, 1997)

Salah satu intervensi yang bisa dilakukan untuk menangani kondisi kurang bahagia yang dialami para santri adalah memberikan pelatihan manajemen stres. Manajemen stres merupakan suatu keterampilan yang dimiliki seseorang untuk mengantisipasi, mencegah, mengelola, dan memulihkan diri dari stres yang dirasakan karena adanya ancaman ketidakmampuan dalam mengatasi stres (Sarafino \& Smith, 2012). Ahli lain, Schafer (2000) menjelaskan bahwa manajemen stres merupakan suatu program untuk melakukan pengendalian atau pengaturan stres yang bertujuan untuk mengenal penyebab stres dan mengetahui teknikteknik mengelola stres, sehingga individu lebih baik dalam menguasai stres dalam kehidupan dan terhindar dari himpitan stres itu sendiri.

Tujuan dari pelatihan manajemen stres ini adalah untuk meningkatkan rasa kebahagiaan santri, seperti penelitian yang dilakukan oleh Fathiyah (2019) bahwa pengelolaan stres sedini mungkin akan meminimalisir afek negatif dan memunculkan kebahagiaan. Taylor (2003) mengungkapkan terdapat tiga tahapan dalam manajemen stres, yakni: (a) Pertama, individu mempelajari apakah stres itu dan bagaimana mengidentifikasi kemunculan sumber stres dalam kehidupan masingmasing individu; (b) Kedua, individu memperoleh dan mempraktekkan keterampilan untuk mengatasi stres; (c) Ketiga, individu mempraktikkan teknik manajemen stres dalam ituasi yang penuh tekanan dan memonitor efektivitas dari kegiatan tersebut.

Harapan positif dari pelaksanaan manajemen stres ini jika diimplikasikan kepada santri akan memiliki pengetahuan dan keterampilan dalam mengelola stres yang muncul dalam kehidupannya, maka ia akan tetap merasa bahagia. Danner, Snowdon, dan Friesen (2001) menegaskan pentingnya afek positif dikembangkan hingga mampu menurunkan afek negatif yang dirasakan, serta meningkatkan kesejahteraan fisik dan psikologis seseorang.

Demikian pentingnya pengelolaan stres agar kondisi tertekan ini tidak benarbenar berdampak negatif (distres) dan menjadi patologis, maka diperlukan upayaupaya peningkatan kebahagiaan melalui pelatihan manajemen stres, serta bermanfaat untuk mendapatkan keterampilan dan pengetahuan baru mengenai manajemen stres, relaksasi otot dan permasalahan pada santri, dan cara mengatasinya, serta upaya yang dapat dilakukan untuk mengembangkan potensi diri yang dimiliki. Mengingat belum banyaknya penelitian dengan tujuan untuk 
mengelola stres yang dihadapi para santri, maka perluya penelitian terkait pelatihan manajemen stres berpengaruh terhadap tingkat kebahagiaan para santri. Hipotesis penelitian ini adalah pelatihan manajemen stres mampu meningkatkan kebahagiaan para santri.

\section{Metode}

\section{Responden penelitian}

Responden penelitian ini adalah 50 santri di pesantren Uswatun Hasanah, terdiri dari santri pria sebanyak 20 orang dan santri perempuan sebanyak 30 orang. Kriteria subjek adalah: 1) skor dari kebahagiaan berada pada kategori sedang dan rendah, diketahui dari hasil instrumen penelitian yakni menggunakan skala kebahagiaan. Cara menetapkan responden penelitian melalui skrining skor kebahagiaan santri; 2) usia 15-18 tahun.

Berdasarkan data Tabel 1, maka yang dijadikan responden dalam penelitian ini adalah santri yang memiliki tingkat kebahagiaan rendah dan sedang yang berjumlah 50 orang. Dari ke 50 santri tersebut, peneliti membagi ke dalam kelompok kontrol dan kelompok eksperimen, yang masing-masing kelompok terdiri dari 25 orang responden.

\section{Instrumen penelitian}

Alat ukur yang digunakan dalam penelitian ini adalah skala kebahagiaan dari

Tabel 1.

Kategorisasi Tingkat Kebahagiaan Santri

\begin{tabular}{llrl}
\multicolumn{4}{l}{ Kategorisasi Tingkat Kebahagiaan Santri } \\
\hline Kategori & Rentang skor & Jumlah & Persentase \\
\hline Rendah & $X<105,61$ & 14 & $14,58 \%$ \\
Sedang & $105,61<X<119,59$ & 36 & $37,5 \%$ \\
Tinggi & $X>119,59$ & 46 & $47,92 \%$ \\
\hline
\end{tabular}

Darmayanti (2012) yang merujuk pada aspek kebahagiaan dari Biswas-Diener, Diener, dan Tamir (2004), yakni: kepuasan hidup (15 aitem, contoh aitem "puas dengan prestasi yang telah saya capai"), afek positif (5 aitem, contoh aitem "hidup yang saya jalani sekarang lebih berwarna"); dan afek negatif (10 aitem, contoh aitem "saya mudah merasa kecewa"). Skala ini terdiri 30 aitem dengan lima alternatif pilihan jawaban, yakni $1=$ tidak pernah hingga $4=$ sangat sering. Nilai reliabilitas untuk skala kebahagiaan adalah 0,913 .

Penyusunan modul pelatihan manajemen stres mengacu pada tiga tahapan manajemen stres dari Taylor (2003), yaitu: Tahap pertama, individu mempelajari apakah stres itu dan bagaimana mengidentifikasi stressor dalam kehidupan masing-masing individu; Tahap kedua, individu memperoleh dan mempraktikkan keterampilan untuk mengatasi (koping) stres; Tahap ketiga, individu mempraktikkan teknik manajemen stres pada situasi yang penuh tekanan dan memonitor efektifitas dari teknik tersebut. Adapun isi ringkasan modul pelatihan manajemen stres adalah pemberian keterampilan kepada para santri dalam upaya untuk meningkatkan kemampuan dalam mengelola stres yang dialami dalam menjalani kehidupan seharihari. Terdapat beberapa materi yang disampaikan, yaitu: pengertian dan gejalagejala stres, dampak dan cara mengelola 
stres, latihan relaksasi, permasalahn remaja, berpikir positif, dan pengembangan potensi diri. Tujuan dari modul pelatihan ini adalah untuk mengurangi kerentanan pribadi individu terhadap stres dan emosi negatif untuk meningkatkan kepuasan hidup para santri.

\section{Desain penelitian}

Penelitian ini menggunakan metode penelitian kuasi eksperimen yang bertujuan untuk mengetahui pengaruh pelatihan manajemen stres terhadap kesejahteraan subjektif santri, dengan variabel bebas adalah pelatihan manajemen stres, dan varibel tergantung adalah kesejahteraan subjektif. Desain penelitian ini menggunakan pretest-posttest control group design, bertujuan untuk membandingkan efek suatu perlakuan terhadap kelompok eksperimen setelah diberikan pelatihan dengan kelompok kontrol yang tidak diberikan pelatihan (Sugiyono, 2017).

\section{Prosedur penelitian}

Penelitian ini terdiri dari dua tahapan, yakni: 1) tahapan persiapan penelitian, terdiri dari: persiapan administrasi, persiapan alat ukur penelitian, persiapan pembuatan modul, seleksi fasilitator; 2) tahapan pelaksanaan penelitian, terdiri dari: pelaksanaan sebelum pelatihan, pelaksanaan saat pelatihan, pelaksanaan setelah pelatihan, dan pelaksanaan tindak lanjut.

Tahap pertama adalah tahapan persiapan penelitian, terdiri dari: 1) persiapan administrasi, peneliti mengurus perizinan ke pesantren, dan menyiapkan informed consent; 2) persiapan alat ukur, peneliti melakukan uji coba skala kebahagiaan pada santri, hasilnya berdasarkan indeks daya beda aitem bergerak -0,181 sampai 0,761 terdapat 10 aitem yang tidak sahih dikarenakan indeks daya beda aitemnya $<0,3$ sehingga jumlah yang digunakan adalah 30 aitem dari 40 total aitem yang digunakan. Selanjutnya dilakukan uji reliabilitas dengan menggunakan alpha Cronbach didapati koefisien reliabilitas skala kebahagiaan sebesar 0,913 dengan $p<0,01$; 3) persiapan pembuatan modul, pembuatan modul manajemen stres disusun sendiri oleh peneliti dengan memodifikasi modul pelatihan manajemen stres yang telah dilakukan oleh peneliti lain yakni Soraya (2018) dan memperhatikan kebutuhan para santri setempat. Modul pelatihan tetap mengacu pada teori manajemen stres dari Taylor (2003) yakni ada tiga tahapan penting, mencakup: pertama, memaknai stres dan bagaimana mengidentifikasi stresor dalam kehidupan individu sendiri; kedua, individu akan memperoleh dan mempraktikkan keterampilan dalam mengatasi (koping) stres yang hadir dalam kehidupannya; ketiga, individu akan mempraktikkan teknik manajemen stres tersebut dalam situasi yang penuh stres dan memonitor efektivitas dari teknik tersebut. Isi modul pelatihan ini terdiri dari beberapa materi, yakni: identifikasi stresor, dampak stres dan pengelolaan stres, remaja dan permasalahannya, latihan relaksasi, berpikir positif, dan pengembangan diri; 4) seleksi fasilitator, penelitian ini disampaikan oleh dua orang psikolog sebagai fasilitator, yang bertugas untuk menyampaikan informasi atau pengetahuan, melatih keterampilan, dan memfasilitasi para santri dalam mempelajari dan mempraktikkan 
pengelolaan stres yang dialami dalam kehidupan sehari-hari.

Tahap kedua adalah tahapan pelaksanaan penelitian, terdiri dari: 1) pelaksanaan sebelum pelatihan, peneliti melakukan uji coba modul kepada lima orang santri yang tidak terlibat pada uji coba alat ukur. Tahapan ini dilakukan mencakup beberapa aspek, yakni kejelasan fasilitator dalam menyampaikan tujuan pelatihan, kesesuaian tujuan pelatihan dengan materi yang disampaikan fasilitator, menarik tidaknya materi pelatihan, dan penyampaian materi pelatihan dengan bahasa yang mudah dipahami, selang waktu yang digunakan dalam pelatihan. Hasil uji coba modul pelatihan manajemen stres tergambar pada Tabel 2.

Berdasarkan uji modul diketahui bahwa secara umum hasil penilaian uji coba modul berdasarkan penilaian kualitatif menunjukkan bahwa tujuan yang hendak dicapai dalam pelatihan manajemen ini sudah sesuai dengan pelatihan yang dilakukan, materi disampaikan dengan bahasa yang jelas dan mudah dipahami; 2) pelaksanaan saat pelatihan, responden penelitian adalah santri yang memiliki tingkat kebahagiaan rendah (14 orang) dan sedang (36 orang) dengan total respon berjumlah 50 orang, dan terbagi ke dalam kelompok kontrol dan kelompok eksperimen, masing-masing berjumlah 25 orang responden. Bagi kelompok eksperimen, diberikan pelatihan manajemen stres selama dua hari, dimulai pukul 08.30-15.00 WIB, sementara untuk kelompok kontrol tidak diberikan perlakuan; 3) pelaksanaan setelah penelitian, dilakukan dengan memberikan skala kebahagiaan kepada kelompok eksperimen dan kelompok control; 4) pelaksanaan tindak lanjut, peneliti melakukan monitoring atas kegiatan pelatihan, yakni dengan memberikan kesempatan bagi santri yang telah menjadi peserta pelatihan untuk menceritakan kembali hal-hal yang dirasakan dan dialami setelah mendapatkan pelatihan.

Tabel 2.

Hasil Penilaian Uji Coba Modul

\begin{tabular}{|c|c|c|}
\hline Santri & Skor rerata & Penilaian kualitatif \\
\hline WS & 4 & $\begin{array}{l}\text { Dapat memahami stres yang sering dialami remaja, mengerti } \\
\text { tentang potensi diri dan tahu apa yang harus dilakukan saat } \\
\text { stres muncul }\end{array}$ \\
\hline ND & 3.8 & $\begin{array}{l}\text { Pelatihan ini menambah pengetahuan tentang stres dan } \\
\text { menjadikan diri lebih paham terkait potensi kelebihan dan } \\
\text { kekurangan yang ada pada diri }\end{array}$ \\
\hline YIM & 3.6 & $\begin{array}{l}\text { Mendapat informasi baru tentang stres dan upaya untuk } \\
\text { mengatisipasinya, sehingga tetap bisa bahagia }\end{array}$ \\
\hline SR & 3.4 & $\begin{array}{l}\text { Pelatihan ini menambah pengetahuan tentang stres dan cara } \\
\text { mengatasinya, memotivasi diri untuk mengembangkan } \\
\text { potensi diri }\end{array}$ \\
\hline MB & 3.2 & $\begin{array}{l}\text { Mendapatkan informasi tentang stres, dampak yang } \\
\text { ditimbulkan dan pengelolaannya, sehingga tahu apa yang } \\
\text { harus dilakukan saat stres muncul nantinya. }\end{array}$ \\
\hline
\end{tabular}




\section{Hasil}

Berdasarkan hipotesis penelitian yakni pelatihan manajemen stres mampu meningkatkan kebahagiaan para santri, maka hasil penelitian menunjukkan terdapat pelatihan manajemen stres terhadap kebahagiaan para santri di pondok pesantren Uswatun Hasanah di kabupaten Labuhanbatu Selatan $(\mathrm{F}(1,48)=$ 9,331, $\mathrm{p}<0,01)$. Untuk hasil perbedaan antara kelompok eksperimen dan kelompok kontrol terlihat pada Tabel 3.

Tabel 3 menjelaskan perbedaan antara kelompok eksperimen dan kelompok kontrol. Pada kelompok eksperimen, hasil analisis untuk aspek kepuasan hidup menunjukkan terdapat perbedaan signifikan rerata kepuasan hidup santri antara kondisi pretest dengan kondisi posttest $(t=8,83, p<0,01)$, dengan nilai rerata kepuasan hidup santri pada kondisi posttest $(M=82,72)$ lebih tinggi dibandingkan dengan kondisi pretest $(M=$ $67,48)$. Pada aspek afek positif ditemukan terdapat perbedaan signifikan rerata antara kondisi pretest dengan kondisi posttest $(\mathrm{t}=$ $6,38, \mathrm{p}<0,01)$, dengan nilai rerata afek positif santri pada kondisi posttest $(M=$ 15,56) lebih tinggi dibandingkan dengan kondisi pretest $(M=11,72)$. Demikian pula untuk hasil analisis pada afek negatif, terdapat perbedaan signifikan pada kelompok eksperimen antara kondisi pretest dengan kondisi posttest ( $t=3,13, p<0,01)$, dengan nilai rerata afek negatif santri pada kondisi posttest $(M=17,32)$ lebih tinggi dibandingkan dengan kondisi pretest $(M=$ 21,20).

Pada kelompok kontrol, hasil analisis untuk aspek kepuasan hidup menunjukkan terdapat perbedaan signifikan rerata kepuasan hidup santri antara kondisi pretest dengan kondisi postest $(t=5,36, p<0,05)$, dengan nilai rerata kepuasan hidup santri pada kondisi posttest $(M=77,04)$ lebih tinggi dibandingkan dengan kondisi pretest $(M=69,04)$. Demikian pada aspek afek positif ditemukan terdapat perbedaan signifikan rerata antara kondisi pretest dengan kondisi posttest $(t=4,86, p<0,01)$, dengan nilai rerata afek positif santri pada kondisi posttest $(M=14,52)$ lebih tinggi dibandingkan dengan kondisi pretest $(M=$ 11,76). Namun untuk hasil analisis pada afek negatif, tidak terdapat perbedaan signifikan pada kelompok kontrol, baik pada kondisi pretest maupun kondisi posttest $(t=0,84, p>0,05)$, dengan nilai rerata afek negatif santri pada kondisi posttest $(M=21,44)$ dan kondisi pretest $(M=$ $20,00)$, nilai rerata berbeda secara nominal,

Tabel 3.

Perbedaan Hasil Kelompok Kontrol dan Kelompok Eksperimen

\begin{tabular}{lcccccccc} 
& \multicolumn{3}{c}{ Kelompok Kontrol } & \multicolumn{3}{c}{ Kelompok Eksperimen } \\
& Kondisi Pretest & \multicolumn{2}{c}{ Kondisi Posttest } & Kondisi Pretest & Kondisi Posttest \\
\hline \multicolumn{1}{c}{ Aspek } & Rerata & SD & Rerata & SD & Rerata & SD & Rerata & SD \\
\hline $\begin{array}{l}\text { Kepuasan } \\
\text { hidup }\end{array}$ & 69,04 & 5,17 & 77,04 & 5,37 & 67,48 & 5.08 & 82,72 & 6,97 \\
$\begin{array}{l}\text { Afek positif } \\
\text { Afek negatif }\end{array}$ & 11,76 & 2,05 & 14,52 & 1,96 & 11,72 & 1.88 & 15,56 & 2,35 \\
\hline
\end{tabular}


namun perbedaan ini tidaklah signifikan. Selanjutnya hasil analisis menemukan pelatihan manajemen stres berkontribusi terhadap kesejahteraan subjektif $\left(R^{2}=0,163\right.$, $p<0,05)$, artinya pengaruh pelatihan manajemen stres terhadap peningkatan kesejahteraan subjektif sebesar 16,3\%.

\section{Diskusi}

Hasil penelitian ini membuktikan pelatihan manajemen stres dapat digunakan untuk meningkatkan kebahagiaan, kepuasan hidup, afek positif, dan meminimalisasi afek negatif para santri yang tinggal di pondok pesantren. Kebahagiaan menjadi faktor penting dalam kehidupan manusia, terutama yang masih berusia muda dalam konteks ini adalah mereka yang berada pada tahap perkembangan remaja. Remaja yang bahagia akan mendorong dan memotivasi usaha untuk mencapai kehidupan yang lebih baik di masa mendatang (Santrock, 2003).

Pada dasarnya tujuan dari manajemen stres adalah untuk mencegah kondisi tertekan menjadi tidak berkepanjangan atau tidak menjadi stres yang kronis; sehingga stres dapat dikelola dengan meredam sumber yang menimbulkan stres, meningkatkan toleransi dan batas ambang daya tahan terhadap stres, serta mengantisipasi akibat fisiologis dari stres itu sendiri. Ini artinya ketika seorang individu memiliki kemampuan ataupun keterampilan dalam bidang manajemen stres, maka stres yang muncul dalam kehidupannya dapat dikelola dengan baik sehingga tidak menyebabkan distress. Beberapa hasil penelitian membuktikan keefektivan pelatihan manajemen stres, di antaranya: 1) penelitian Chraif (2015) menemukan bahwa semakin baik kemampuan adaptasi dan manajemen stres seseorang, maka semakin rendah pula tingkat stres akademik yang dirasakan meskipun stresor akademiknya sangat kuat; 2) manfaat manajemen stres juga dirasakan mampu mengurangi kecemasan dan meningkatkan penyesuaian diri bagi mahasiswa baru (Suranadi, 2012); 3) tuntutan beban tugas yang semakin kompleks disertai hubungan yang tidak harmonis di tempat kerja merupakan sumber utama munculnya stres pada pekerja, berbagai program manajemen stres telah banyak diupayakan dan manfaatnya dirasakan dalam memunculkan kebahagiaan dalam bekerja (Purnawati, 2014); 4) para lanjut usia yang memiliki penyakit kronis juga dirasakan rentan mengalami stres, hasil penelitian oleh Hanum, Daengsari, dan Kemala (2016) tentang peran manajemen stres secara berkelompok dalam menurunkan stres lansia terbukti efektif; 5) peran pelatihan manajemen stres dalam meningkatkan kebahagiaan (Nath \& Pradhan, 2012); 6) meningkatnya afek positif terhadap regulasi diri melalui program manajemen stress (Pavani, Le Vigouroux, Kop, Congard \& Dauvier, 2016); 7) pentingnya peran afek positif dalam bidang akademik (Schutz \& Lanehart, 2002), dan efektivitas proses pembelajaran (Goetz, Pekrun, Hall \& Haag, 2006).

Pentingnya pelatihan manajemen stres telah dibuktikan dari riset-riset sebelumnya dan diaplikasikan pada responden penelitian yang bervariasi. Temuan ini mengimplikasikan bahwa pelatihan manajemen stres dapat 
digunakan untuk meningkatkan kebahagiaan santri yang tinggal di pondok pesantren. Ketika santri mampu memahami dan mengimplementasikan pengetahuan serta ketrampilan manajemen stres yang telah dilatihkan, maka rasa homesickness, aturan dan jadwal yang ketat, penyesuaian dengan lingkungan akan dapat dengan mudah diatasinya. Artinya para santri akan mampu mengembangkan koping atas tekanan-tekanan hidup yang dirasakannya selama berada di pondok pesantren. Dampak positifnya adalah kebahagiaan akan meningkat, sehingga mereka akan mampu mengembangkan potensi psikologis secara optimal.

$$
\text { Hasil penelitian ini juga }
$$

menemukan tinjauan kebahagiaan berdasarkan pada masing-masing aspeknya, yakni peningkatan pada aspek kepuasan hidup dan aspek afek positif. Pelatihan manajemen stress membukakan wacana atau pengetahuan baru bagi para santri dalam menyikapi kehidupan yang dialami selama di pesantren. Para santri mampu mengevaluasi secara kognitif dan afektif peristiwa ataupun kejadian-kejadian dalam hidupnya dan memaknai setiap kejadian tersebut secara positif. Mereka mampu mengambil hikmah dari apa yang dirasakan dan dipikirkannya.

Para santri juga mengalami penurunan pada aspek afek negatifnya. Hal ini dipengaruhi oleh efektifitas pelatihan manajemen stres bagi peningkatan kebahagiaan santri, sehingga afek negatif yang dirasakan bukan menjadi penghambat bagi santri. Kondisi ini didukung pendapat dari Carr (2011) yang menyatakan bahwa kebahagiaan merupakan kondisi psikologi yang positif, yang ditandai dengan kepuasan hidup, tingginya emosi positif dan rendahnya emosi negatif. Pentingnya penelitian dalam menangani kondisi stres santri juga diperkuat oleh riset yang dilakukan Ramadhan (2012) yakni peran kesejahteraan psikologis dalam meminimalisasi stress bagi santri penghapal Al Quran, stres juga dapat diminimalisasi melalui efektivitas sholat tahajud bagi santri (Azzam \& Abidin, 2014), pelatihan relaksasi dzikir dalam menurunkan stres santri (Kusumadewi, 2015).

\section{Kesimpulan}

Hasil penelitian ini mampu membuktikan hipotesis bahwa terdapat pengaruh pelatihan manajemen stres terhadap kebahagiaan para santri, artinya santri mampu mengelola stres, memiliki kepuasan hidup, dan mengalami peningkatan untuk afek positif dibandingkan afek negatif, dan tetap merasa bahagia meskipun banyak tekanan yang dirasakan dari lingkungannya.

\section{Saran}

Saran yang dapat diberikan dari hasil penelitian ini di antaranya: Pertama, kepada pengelola pondok pesantren agar dapat melaksanakan pelatihan manajemen stres secara berkelanjutan. Hal ini dapat dilakukan dengan mengembangkan program TOT (training of trainer), sehingga santri yang telah mendapatkan pengalaman pelatihan manajemen stres dapat melatih santri lainnya di kemudian hari. Hasil penelitian ini menunjukkan terdapat peningkatan kebahagiaan (baik pada aspek kepuasan hidup, afek positif, dan afek 
negatif) setelah pemberian pelatihan manajemen stres, maka diharapkan santri dapat mempertahankan rasa kebahagiaannya dengan senantiasa menggali informasi dan pengetahuan, serta keterampilan dalam mengelola stres, kemudian diharapkan mampu mengaplikasikan pengetahuan tersebut dalam kehidupan sehari-hari. Kedua, penelitian ini tidak melibatkan faktor-faktor lain yang diduga dapat memunculkan perasaan bahagia santri, seperti faktor demografi, sosial ekonomi keluarga, dukungan sosial dari ustadz dan ustadzah, dan prestasi yang telah dicapai. Dengan demikian, diharapkan kepada peneliti selanjutnya untuk dapat melibatkan faktorfaktor tersebut dalam memengaruhi kebahagiaan para santri yang tinggal di pondok pesantren.

\section{Daftar Pustaka}

Aminullah, A. (2013). Kecemasan antara dan siswa SMP dan santri pondok pesantren. Jurnal Ilmiah Psikologi Terapan, 1(2), 205-215.

Argyle, M. (2001). The psychology of happiness (Edisi kedua). New York: Routledge.

Azam, S. M., \& Abidin, Z. (2014). Efektivitas shalat tahajud dalam mengurangi tingkat stres santri. JIP (Jurnal Intervensi Psikologi), 6(2), 171180.

Biswas-Diener, R., Diener, E., \& Tamir, M. (2004). The psychology of subjective well-being. Daedalus, 133, 18 -25. doi: https://doi.org/10.1162/0011526043230 $\underline{49352}$
Carr, A. (2011). Positive psychology: The science of happiness and human strengths (Edisi kedua). New York: Routledge.

Chraif, M. (2015). Correlative study between academic satisfaction, workload and level of academic stress at 3rd grade students at psychology. Procedia-Social and Behavioral Sciences, 203, 419-424. doi: https://doi.org/10.1016/j.sbspro.2015.0 $\underline{8.317}$

Danner, D. D., Snowdon, D. A., \& Friesen, W. V. (2001). Positive emotions in early life and longevity: Findings from the nun study. Journal of Personality and Social Psychology, 80(5), 804-813.

doi: https://doi.org/10.1037/0022-

\subsubsection{4}

Darmayanti, N. (2012). Model kesejahteraan subjektif remaja penyintas bencana tsunami Aceh 2004 (Disertasi tidak dipublikasikan). Yogyakarta: Program Doktor Psikologi, Fakultas Psikologi, Universitas Gadjah Mada.

Fathiyah, K.N. (2019). Peran afek positif terhadap stres akademik dengan dimediasi koping proaktif, orientasi tujuan penguasaan, dan regulasi emosi pada siswa SMP (Disertasi tidak dipublikasikan). Yogyakarta: Program Doktor Psikologi, Fakultas Psikologi, Universitas Gadjah Mada.

Fields, L., \& Prinz, R. J. (1997). Coping and adjustment during childhood and adolescence. Clinical Psychology Review, 17(8), 937-976. doi: https://doi.org/10.1016/S0272-

\section{$\underline{7358(97) 00033-0}$}

Goetz, T., Pekrun, R., Hall, N., \& Haag, L. (2006). Academic emotions from a 
social-cognitive perspective: Antecedents and domain specificity of students' affect in the context of Latin instruction. British Journal of Educational Psychology, 76(2), 289-308. doi:

https://doi.org/10.1348/000709905X428 $\underline{6}$

Hanum, L., Daengsari, D. P., \& Kemala, C. N. (2016). Penerapan manajemen stres berkelompok dalam menurunkan stres pada lanjut usia berpenyakit kronis. Jurnal Psikologi, 43(1), 42-51.

Kusumadewi, A. (2015). Pelatihan relaksasi dzikir untuk menurunkan stress santri Rumah Tahfidz Z (Tesis tidak dipublikasikan). Yogyakarta: Fakultas Psikologi dan Ilmu Sosial Budaya, Universitas Islam Indonesia.

Nath, P., \& Pradhan, R. K. (2012). Influence of positive affect on physical health and psychological well-being: Examining the mediating role of psychological resilience. Journal of Health Management, 14(2), 161-174. doi:

https://doi.org/10.1177/0972063412014 $\underline{00206}$

Pavani, J. B., Le Vigouroux, S., Kop, J. L., Congard, A., \& Dauvier, B. (2016). Affect and affect regulation strategies reciprocally influence each other in daily life: The case of positive reappraisal, problem-focused coping, appreciation and rumination. Journal of Happiness Studies, 17(5), 2077-2095. doi: $\quad$ https://doi.org/10.1007/s10902015-9686-9

Purnawati, S. (2014). Program manajemen stres kerja di perusahaan: sebuah petunjuk untuk menerapkannya. Buletin

Psikologi, 22(1), 36-44.

Ramadhan, Y. A. (2012). Kesejahteraan psikologis pada remaja santri penghafal Al-quran. Psikologika: Jurnal Pemikiran dan Penelitian Psikologi, 17(1), 19-32.

Santrock, J. W. (2003). Adolescence: perkembangan Remaja (Edisi keenam). Jakarta: Penerbit Erlangga

Sarafino, E.P \& Smith, T.W. (2012). Health psychology: Biopsychosocial interactions (Edisi ketujuh). New Jersey: John Wiley \& Sons.

Schafer, W. (2000). Stres management for wellness. Fourth edition. United State of America; Wadsworth.

Schutz, P. A., \& Lanehart, S. L. (2002). Introduction: Emotions in education. Educational Psychologist, 37(2), 67-68. doi:

https://doi.org/10.1207/S15326985EP3 702_1

Soraya, R.N. (2018). Pelatihan manajemen stress untuk meningkatkan kesejahteraan subjektif pada penderita asma (Tesis tidak dipublikasikan). Yogyakarta, Program Studi Magister Psikologi Profesi, Fakultas Psikologi dan Ilmu Sosial Budaya, Universitas Islam Indonesia.

Sugiyono. (2017). Metode penelitian kombinasi (Mixed methods). Bandung: Alfabeta.

Suranadi, L. (2012). Manajemen stres mahasiswa baru. Jurnal Kesehatan Prima, 6(2), 942-947.

Taylor, S. (1995). Health psychology (Edisi ketiga). New York: McGrawHill.

Taylor, S. (2003). Health psychology (Edisi internasional). New York: McGrawHill. 


\section{DARMAYANTI \& DAULAY}

Yasmin, M., Zulkarnain, \& Daulay, D.A. (2017). Gambaran homesickness pada siswa baru di lingkungan pesantren.
Psikologia: Jurnal Pemikiran dan

Penelitian Psikologi, 12(3), 165 -172. 